\title{
HUBUNGAN PENGAWASAN TERHADAP KEPATUHAN PENGUNAAN APD DI RUMAH SAKIT UMUM UNIVERSITAS KRISTEN INDONESIA
}

\author{
Sabarina Elprida Manik ${ }^{1}$, Dian Utari ${ }^{2}$ \\ ${ }^{1}$ Ahli Teknologi Laboratorium Medis /Universitas Respati Indonesia \\ ${ }^{2}$ Ahli Teknologi Laboratorium Medis /Sekolah Tinggi Ilmu Kesehatan M.H Thamrin \\ Korespondensi : ${ }^{1}$ sabarina.elfrida@binawan.ac.id, ${ }^{2}$ dian.utari789@gmail.com
}

\begin{abstract}
Abstrak
Rumah Sakit Universitas Kristen Indonesia merupakan rumah sakit yang bertujuan menyelenggarakan kesehatan dengan mengantisipasi perubahan-perubahan global yang mengunggulkan pelayanan keperawatan yang professional. Kepatuhan Petugas Rumah Sakit dalam penggunaan Alat Pelindung Diri adalah salah satu upaya peningkatan mutu pelayanan kesehatan yang bertujuan untuk mengendalikan infeksi, mengingat tingginya berbagai penyakit yang ditularkan melalui darah dan cairan tubuh lainnya di lingkungan pelayanan kesehatan. Tujuan penelitian ini adalah untuk mengetahui factor-faktor yang mempengharui petugas dalam pengunaan Alat Pelindung Diri di Rumah Sakit Universitas Indonesia tahun 2017. Jenis penelitian ini menggunakan pendekatan kuantitatif melalui desain penelitian cross dari unit Laboratorium dan 89 responden dari unit keperawatan. Analisis data dilakukan dengan menggunakan uji Chi Square. Hasil: berdasarkan penelitian menunjukkan presentase tidak pernah ada pengawasan, 47 responden $(44,3 \%)$.
\end{abstract}

Kata kunci: Kepatuhan, Alat Pelindung Diri, Infeksi

\section{COMPLIANCE WITH THE USE OF SELF-PROTECTIVE EQUIPMENT IN THE LABORATORY AND INPOSITION OF UKI HOSPITAL}

\begin{abstract}
Hospital University Christian Indonesia is a hospital that aims to provide health care by anticipating global changes that promote professional nursing services. Hospital staff compliance with the use of Personal Protective Equipment is an effort to improve the quality of health service aimed at controlling infection, given the high number of diseases transmitted through blood and other body fluids in the health service environment. The purpose of this study is to determine the factors that update officers in the use of Personal Protective equipments at the Hospital University Christian Indonesia in 2017. This type of research uses a quantitative approach through a cross-research design from the Laboratory unit and 89 respondents from the nursing unit. Data analysis was performed using the Chi Square test. Result: based on the study, the percentage was never any supervision, 47 respodndents $(44,3 \%)$.
\end{abstract}

Keywords: Compliance, Personal Protective equipments, Infection 


\section{PENDAHULUAN}

Salah satu upaya dalam rangka pemberian perlindungan tenaga kerja terhadap keselamatandan kesehatan kerja di rumah sakit adalah dengan memberikan alat pelindung diri. Pemberian alat pelindung diri kepada tenaga kerja. Alat pelindung diri Merupakan salah satu alat yang harus digunakan oleh petugas kesehatan untuk melindungi diri dari kontak bahaya, baik bersifat kimia, biologis, radiasi, fisik, elektrik, dan mekanik. Pemberian alat pelindung diri merupakan upaya terahir apabila upaya rekayasa (engineering) dan cara kerja yang aman (work pracktices) telah maksimal dilakukan. Hal ini tercermin dalam Undang - Undang No. 1 tahun 1970 tentang keselamatan kerja pasal 3, 9, 12, 14, dinyatakan bahwa dengan peraturan perundang undangan ditetapkan syarat syarat keselamatan dan kesehatan kerja untuk memberikan alat pelindung diri. Hal ini sejalan dengan Kewaspadaan Universal atau Universal Precautions yaitu suatu pedoman yang ditetapkan Centers for Disease Control pada tahun 1987 yang bertujuan mencegah penyebaran berbagai penyakit yang ditularkan melalui darah dan cairan tubuh lainnya di lingkungan sarana pelayanan kesehatan.

Berdasarkan data menurut jamsostek (2011) bahwa angka kecelakaan kerja di Indonesia mencapai 99,491 kasus yang diakibatkan kelainaan penggunaan APD secara umum pada beberapa unit kerja. Hasil studi pendahuluan yang telah dilakukan di rumah sakit Sari Asih Serang peovinsi Banten dengan cara observasi, di dapatkan data distribusi frekuensi ketidapatuhan perawat dalam penggunaan APD yaitu ruangan ICU (39\%), perinatologi $(62 \%)$, ruang anak (79\%), ruang perawatan umum (76\%), IGD (63\%), dan ruang VIP $(45,8 \%)$, dengan jumlah rata-rata perawat ditiap ruangan sebanyak 20 orang perawat (Asri Asmi, 2017).

Keselamatan kerja ialah sarana utama untuk pencegah kecelakaan, cacat, dan kematian sebagai akibat kecelakaan kerja, Keselamatan kerja yang baik adalah pintu gerbang bagi keamanan tenaga kerja.
Keselamatan kerja bertujuan untuk membuat tenaga kerja mendapatkan perlindungan keselamatan pada pekerjaannya dari bahaya -bahaya kecelakaan yang bersumber kepada mesin dan peralatan kerja, lingkungan dan faktor-faktor manusia sendiri. Sedangkan Kesehatan kerja ialah praktek-praktek meningkatkan kesehatan tenaga kerja yang setinggi tingginya, baik kuratif maupun preventif. Sasarannya adalah faktor manusia dan lingkungan. Tujuan akhir dari peningkatan kesehatan kerja Begitu juga dengan petugas rumah sakit umum UKI khususnya petugas laboratorium dan perawat, sebelum berperilaku melakukan aktivitas, petugas tersebut harus memiliki pengetahuan, kesadaran, dan sikap yang positif tentang alat pelindung diri.

Pada tahun 2002, WHO menetapkan 2 juta pekerja kesehatan terinfeksi virus hepatitis $\mathrm{B}, 0,9$ juta pekerja terinfeksi virus hepatitis C, 170.000 terpajan virus HIV/AIDS. Di Amerika serikat lebih dari 8 juta petugas kesehatan di rumah sakit terpajan darah atau cairan tubuh lainnya, diantaranya melalui jenis kontak luka dengan instrumen tajam yang terkontaminasi seperta jarum dan pisau bedah (82\%), kontak dengan selaput lendir mata, hidung dan mulut (14\%), terpajan dengan kulit yang terkupas atau rusak (3\%), dan gigitan manusia (1\%). Menurut propil kesehatan propinsi jawa tengah (tahun 2012) di Indonesia khususnya di jawa tengah kasus penyakit menular sangat tinggi yaitu tahun 2012 sebesar 106,42 per 100.000 penduduk terserang TB 607 kasus HIV, dan 98 kasus hepatitis B.

Rumah Sakit umum UKI merupakan rumah sakit yang bertujuan menyelenggarakan kesehatan dengan mengantisipasi perubahan-perubahan global yang mengunggulkan pelayanan keperawatan yang profesional. Ada berbagai fasilitas pelayanan di rumah sakit umum UKI, yaitu adanya pelayanan medis rawat inap dan rawat jalan, penunjang medis, pelayanan dan asuhan keperawatan, pelayanan rujukan (sistem referal), pendidikan dan pelatihan, penelitian dan 
pengembangan, administrasi umum dan keuangan. Berdasarkan pengamatan penulis di rumah sakit umum UKI berkaitan dengan kepatuhan penggunaan APD pada bagian laboratorium dan keperawatan masih rendah. Berdasarkan pengamatan tersebut perlu di ketahui lebih lanjut faktor - faktor yang mempengaruhi kepatuhan dalam pengunaan alat pelindung diri (APD) di ruang laboratorim dan di ruang rawat inap di rumah sakit umum UKI Cawang Jakarta Timur tahun 2017.

\section{BAHAN dan METODE}

Jenis penelitian ini menggunakan metode analisis kuantitatif melalui desain penelitian cross sectional, dimana objek penelitian atau responden akan diukur melalui survey (kuesioner) secara bersamaan diukur variabel dependent dan independent dalam satu waktu tertentu untuk mengetahui faktor-faktor yang berhubungan petugas dalam penggunaan alat pelindung diri di Rumah sakit UKI tahun 2017. Penelitian ini dilaksanakan pada petugas Laboratorium dan keperawatan (rawat inap) Rumah Sakit umum UKI pada bulan Mei - Juni 2017. Kuesioner ini berisi pertanyaan untuk mengali informasi dari responden tentang kepatuhan dalam penggunaan APD. Kamera digunakan untuk medokumentasikan kegiatan penelitian dan proses kerja di rumah sakit UKI.

Populasi yang diteliti adalah pekerja di Rumah Sakit Umum UKI khususnya di instalasi laboratorium sebanyak 17 responden dan instalasi keperawatan (rawat inap) sebanyak 89 responden, jumlah keseluruhan 106 responden. Pengambilan sampel menggunakan total populasi, yaitu 17 responden petugas laboratorium dan 89 responden petugas keperawatan, jumlah keseluruhan sampel 116 responden.

\section{HASIL}

RSU UKI adalah salah satu lembaga di jajaran UKI yang pendiriannya terkait dengan FK UKI. Karena itu sejarah pendirian RSU UKI tidak terlepas dari keberadaan FK UKI. Pimpinan Fakultas Kedokteran Universitas Kristen Indonesia
(FK UKI) yang pertama adalah dr. SC Nainggolan, MPH (Alm) sebagai Dekan dan dr. H. Sinaga sebagai sekretaris telah berhasil mendirikan FK dan RS Puskesmas FK UKI yang diperuntukkan sebagai "Teaching Hospital" yang merupakan sumbangan DR. Beckmann ketua EKIR (Evangelische Kirche Im Rheinland) Jerman Barat diresmikan pada tanggal 1 Desember 1973 oleh Menteri Kesehatan RI, cita-cita tersebut baru terwujud 10 tahun kemudian. Diatas tanah pada lahan seluas $13 \cdot 220,30 \mathrm{~m}^{2}$ dengan luas bangunan kurang lebih 1.593 $\mathrm{m}^{2}$, mendapat bantuan dana yang merupakan partisipasi seluruh mahasiswa FK UKI berupa iuran pembelian tanah $5 \mathrm{~m}^{2}$ per mahasiswa serta biaya sumbangan untuk rumah sakit dan pendidikannya. Sesuai dengan maksud pendirian RS Puskesmas FK UKI yakni sebagai teaching hospital bagi mahasiswa - mahasiswi FK, maka pengelolaan RS Puskesmas FK UKI pada awal pendiriannya langsung berada di bawah Dekan FK dan pada fase ini RS Puskesmas FK UKI mencatat berbagai perkembangan, diantaranya penyediaan jumlah tempat tidur. Saat didirikan, RS Puskesmas FK UKI hanya memiliki 32 tempat tidur, namun dalam kurun waktu sekitar 13 tahun jumlah tempat tidur meningkat menjadi 200 Bed. Peningkatan tersebut sejalan dengan penambahan alat-alat kedokteran. Tahun 1982 RS Puskesmas FK UKI berganti nama menjadi Rumah Sakit Umum Fakultas Kedokteran Universitas Kristen Indonesia (RSU FK UKI) yang dalam penyelenggaraannya bertanggungjawab dan bernaung dibawah FK UKI, pada masa ini berbagai perbaikan dilakukan, misalnya perbaikan dibidang administrasi dan keuangan. Kebutuhan akan alat-alat kedokteran/alat medis di ICU dan kamar bedah juga dilengkapi serta diberikannya dua unit ambulance untuk RSU FK UKI, kendati demikian dari segi keuangan rumah sakit masih mengalami defisit.

Pada tahun 1990 pengelolaan RSU FK UKI melakukan manajemen secara mandiri khususnya dibidang ketenagaan dan keuangan ditahun ini juga RSU FK UKI mempunyai Dewan Direksi dengan Motto 
"melayani bukan dilayani". Manajemen RSU FK UKI langsung bertanggungjawab kepada Yayasan UKI. Mencermati perkembangan yang pesat dari RSU FK UKI maka pemerintah merasa perlu membantunya. Tahun 1990 Depkes RI menyerahkan sumbangan alat-alat kesehatan eks Jepang senilai 800 juta rupiah kepada RSU FK UKI. Alat ini dipakai untuk meningkatkan mutu pelayanan UGD. Selain itu juga menerima alat-alat kedokteran dari negeri Belanda. Pada tahun yang sama, ketua Yayasan UKI Bapak Soedarjo turut juga membantu memajukan RSU FK UKI dengan mendirikan bangunan VIP dan kelas 1 Utama dengan tempat tidur sebanyak 20 Bed. Peningkatan pelayanan ini mengundang masyarakat turut membantu, ini terbukti dengan disumbangkannya 3 buah ambulan kepada RSU FK UKI oleh PT Jasa Raharja dan PT maskapai Asuransi Sari Sumber Agung. Selain itu tahun 1994, Pemda DKI menyerahkan sumbangan berupa CT-Scan kepada RSU FK UKI. Keberadaan alat ini bagi RSU FK UKI sangat vital mengingat RSU FK UKI sebagai RS Trauma Center dan banyak menerima pasien trauma terutama dari kecelakaan jalan tol.

Seiring dengan tuntutan masyarakat, pada tahun 1996, RSU FK UKI membangun ruangan Super VIP dan penambahan ruangan kelas II sehingga sampai saat ini tercatat jumlah TT sebanyak 224 buah. Fasilitas penunjang lainnya ditambah adalah Unit Hemodialisis, Rehabilitasi Medis dan Fisioterapi, Endoskopy, Ultrasonografi, Laboratorium Klinik, Apotik, Radiologi dan Bank Darah. Pertambahan fasilitas pelayanan dan penunjang tersebut berdampak kepada pertambahan Sumber Daya Manusia sebagai pengelola. Sejak tahun 2000 RSU FK UKI ditempatkan dalam naungan Yayasan Universitas Kristen Indonesia (YUKI) dalam rangka menyesuaikan dengan tuntutan Undang-Undang dan Peraturan yang berlaku dimana rumah sakit menjadi suatu institusi mandiri dibawah sebuah yayasan. Pada tanggal 30 April 2008 RSU UKI telah mendapatkan izin penyelenggaraan RS yakni Keputusan Menkes RI No. HK.07.06/III/1460/08. Tahun 2009 pada SK YUKI Nomor: 125/YUKI/RSU.402/06.09 terjadi perubahan nama Rumah Sakit Umum Fakultas Kedokteran Universitas Kristen Indonesia (RSU FK UKI) menjadi Rumah Sakit Umum Universitas Kristen Indonesia (RSU UKI) dengan tidak mengurangi fungsi pendidikan sebagai Fakultas Kedokteran Universitas Kristen Indonesia (FK UKI). Pada tanggal 23 Desember 2010 IGD RSU UKI telah mendapatkan Sertifikasi dari badan ISO 9001:2008 (QEC28334) yang diselenggarakan oleh SAI Global Limited. Pada tanggal 22 Maret 2011 RSU UKI telah mendapatkan Sertifikat Akreditasi Penuh untuk 12 pelayanan yaitu: Administrasi dan Manajemen, Pelayanan Medik, Pelayanan Gawat Darurat, Keperawatan, Rekam Medik, Farmasi, Keselamatan Kerja, Kebakaran dan Kewaspadaan Bencana (K3), Radiologi, Laboratorium, Kamar Operasi, Pengendalian Infeksi dan Perinatal Resiko Tinggi yang diselenggarakan oleh Komite Akreditasi RS (KARS). Selanjutnya pada Oktober 2011 RSU UKI ditetapkan sebagai RS Pendidikan Utama FK UKI melalui SK Menteri Kesehatan RI no. HK.03.05/III/2462/2011.

Visi:

"Menjadi Rumah Sakit Pendidikan Utama yang Mempunyai Keunggulan Kompetitif Dalam Pelayanan, Pendidikan Dan Penelitian Di Bidang Kesehatan". Misi:

1. Membangun karakter dokter yang memiliki sistem nilai Kristen berdasarkan kasih dalam menjalankan kompetensinya.

2. Menyelenggarakan \& mengembangkan pendidikan kedokteran, penelitian dan pelayanan medis dasar dan spesialistik berkualitas sesuai dengan kebutuhan pendidikan dengan keunggulan kompetitif khususnya dalam bidang trauma dan penyakit tropis.

3. Menjalankan kegiatan operasional secara efektif dan efisien serta sinergis sehingga menghasilkan nilai tambah bagi stakeholders (pelanggan, pekerja, mitra kerja, pemilik dan masyarakat). 
4. Mengembangkan dan memperkuat manajemen RS pendidikan yang mandiri dan mempunyai tatakelola yang baik (Good Teaching Hospital Governance)

Nilai-nilai RSU UKI:

1. Rendah Hati

2. Berbagi dan Peduli

3. Profesional

4. Bertanggung Jawab

5. Disiplin \& Jujur

Tabel 1. Rangkuman hasil analisis Bivariat

\begin{tabular}{llll} 
No. & Variabel & P-Velue & Kesimpulan \\
\hline 1. & Umur & 0,036 & Ada hububgan yang signifikan \\
2. & Jenis kelamin & 0,175 & Tidak ada hubungan yang signifikan \\
3. & Pengetahuan & 0,000 & Ada hububgan yang signifikan \\
4. & Pendidikan & 0,270 & Tidak ada hubungan yang signifikan \\
5. & Lama bekerja & 0,165 & Tidak ada hubungan yang signifikan \\
6. & Pengawasan & 9,944 & Tidak ada hubungan yang signifikan \\
7. & Pelatihan & 0,000 & Ada hubuNgan yang signifikan \\
Rumus: & &
\end{tabular}

$$
\mathrm{P}=\frac{F}{N} \times 100 \%
$$

Keterangan :

$\mathrm{P}$ : Presentase Distribusi frekuensi

$\mathrm{N}$ : Jumlah semua pertanyaan

$\mathrm{F}$ : Jumlah pertanyaan yang dijawab benar oleh responden

$$
x^{2}=\sum \frac{(\mathrm{O}-\mathrm{E})^{2}}{\mathrm{E}} .
$$

Keterangan :

$\sum=$ jumlah

$\mathrm{O}=$ Nilai observasi

$\mathrm{E}=$ Nilai ekspektasi (harapan)

$\mathrm{X}=$ Chi-square

\section{PEMBAHASAN}

Keterbatasan dalam penelitian ini adalah pengumpulan data dengan menggunakan kuesioner, maka kebenaran dalam memperoleh data sangat ditentukan oleh kejujuran responden (petugas Rs bagian laboratorium dan keperawatan) pada saat menjawab pertanyaan. Selain itu peneliti juga mempunyai keterbatasan dalam hal waktu, dana yang tersedia serta kemampuan peneliti dalam menganalisa data. Peneliti menggunakan rancangan cross-sectional, dengan menggunakan pendekatan observasi pada satu waktu dan juga keterbatasan kemampuan peneliti dalam menganalisis data dan pelaksanaan dilapangan, maka tidak semua variabel yang berhubungan dengan kepatuhan penggunaan APD dapat diteliti.

Pada penelitian di RSU UKI di ruang laboratorium dan ruang rawat inap periode juni sampi dengan juli 2017,hasil analisis hubungan antara lama bekerja dengan kepatuhan dalam pengguan APD bahwa sebanyak responden yang termasuk dalam kelompok tidak pernah pengawasan yang tidak patuh dalam penggunaan APD sebesar 37 responden $(78,7 \%)$ dan 16 responden $(27,1 \%)$. Dengan nilai $\mathrm{p}$ value 0,000 yang berarti adanya hubungan antara pengawasan dengan kepatuhan menggunakan APD. Dengan nilai OR 9,944 yang berarti kelompok yang tidak pernah pengawasan memiliki 9,944 kali beresiko tidak patuh dalam penggunaan APD.

\section{SIMPULAN dan SARAN Simpulan}

Berdasarkan hasil yang didapat dalam penelitian ini, maka dapat disimpulkan bahwa kepatuhan petugas RSU UKI khususnya bagian Laboratorium dan Keperawatan masih rendah. Hal ini sangat beresiko atau berpotensi menimbulkan bahaya bagi petugas yang dapat menggangu kesehatan sehingga akan menggangu produktifitas kerja dan berdampak terhadap mutu layanan yang di berikan. Hubungan antara Pengawasan dengan kepatuhan penggunaan APD tidak terdapat hubungan yang bermakna. Hasil uji statistik dengan chi square diperoleh $\mathrm{P}$-value $=0,420 \geq 0,05$.

\section{Saran}

Berdasarkan hasil penelitian tersebut, peneliti memberikan beberapa saran yang diharapkan dapat membantu pihak Rumah Sakit Universitas Kristen Indonesia dalam memperbaiki dan mencapai angka kepatuhan petugas yang tinggi terhadap penggunaan Alat Pelindung Diri.

\section{UCAPAN TERIMA KASIH}

Penulis mengucapkan terima kasih banyak kepada semua pihak yang telah memberikan dukungan dan kontribusi terhadap penelitian ini. 


\section{DAFTAR PUSTAKA}

Asmi, Asri , 2017 . Faktor-faktor yang

Berhubungan dengan Kepatuhan Perawat Dalam Penggunaan APD di Ruang Rawat Inap RS. Bhayangkara Makassar . Skripsi . Fakultas Kedokteran dan Ilmu Kesehatan UIN Alauddin Makassar

Fakultas Kedokteran UKI . Struktur Organisasi, Jakarta : FK UKI.

Harwanti, Nunik . 2009 . Pemakaian Alat Pelindung Diri Dalam Memberikan Perlindungan Bagi Tenaga Kerja Di Instalasi Rawat Inap I RSUP Dr.Sardjito Yogyakarta.Fakultas Kedoketran Universitas Sebelas Maret Surakarta.

Kemendikbud . Keselamatan Kerja dan Persyaratan Kerja, Jakarta : Kemendikbud RI.

Kemenkes, 2014. Situasi dan Analisis Hepatitis, Jakarta : Kemenkes RI.

Menkes RI . 2011 . Surak Keputusan Menteri Kesehatan RI Nomor HK 03.05/III/2462/2011 tentang RSU UKI ditetapkan sebagai RS Pendidikan Utama FK UKI.

Yayasan UKI. Surat Keputusan YUKI Nomor: $\quad$ 125/YUKI/RSU.402/06.09 terjadi perubahan nama Rumah Sakit Umum Fakultas Kedokteran Universitas Kristen Indonesia (RSU FK UKI) menjadi Rumah Sakit Umum Universitas Kristen Indonesia (RSU UKI) 